\title{
KAJI EKSPERIMENTAL PENGARUH BAFFLE PADA ALAT PENUKAR PANAS ALIRAN SEARAH DALAM UPAYA OPTIMASI SISTEM PENGERING
}

\author{
Azwinur ${ }^{1, *}$, Zulkifli $^{2}$ \\ ${ }^{1,2}$ Jurusan Teknik Mesin Politeknik Negeri Lhokseumawe \\ Jl. Banda Aceh-Medan Km. 280 P.O. Box 90 Buketrata, Lhokseumawe 24301 \\ *E-mail: azwinur@pnl.ac.id \\ Diterima: 16-01-2019 \\ Direvisi: 10-03-2019 \\ Disetujui: 01-06-2019
}

\begin{abstract}
ABSTRAK
Heat exchanger atau alat penukar/pemindah panas adalah alat-alat yang digunakan untuk mengubah temperatur fluida atau mengubah fasa fluida dengan cara mempertukarkan panasnya dengan fluida lain. Pada sebuah penukar panas, kemampuan mempertukarkan panas sangat ditentukan oleh jenis aliran fluida dan fluida yang melewati penukar panas. Penggunaan penukar panas dalam bidang pengeringan saat ini sudah menjadi kebutuhan untuk mengatasi permasalahan produktifitas pengeringan. Tujuan dilakukan penelitian ini dilakukan untuk mengetahui efektifitas penukar panas secara eksperimental berdasarkan aliran searah dengan membandingkan konstruksi yang menggunakan baffle dan tanpa menggunakan baffle dalam upaya optimasi sistem pengeringan. Metode penelitian dilakukan fabrikasi 2 unit alat penukar panas dan dengan pengujian lapangan. Data pengujian yang diperoleh adalah temperatur input dan output aliran fluida pemanas dan aliran fluida pendingin serta kecepatan aliran. Berdasarkan data hasil penelitian awal menujukkan bahwa penggunaan baffle mempengaruhi peningkatan temperatur pada alat penukar panas, dimana pada aliran outlet fresh air yang tidak menggunakan baffle menghasilkan temperature sebesar $72^{\circ} \mathrm{C}$ sedangkan yang menggunakan baffle menghasilkan temperature sebesar $88^{\circ} \mathrm{C}$ dengan Nilai Log Mean Temperature Difference penukar panas tanpa menggunakan baffle lebih tinggi daripada penukar panas yang menggunakan baffle. Hal ini bisa menggambarkan bahwa pelepasan panas (heat losses) semakin kecil yang terbuang sehingga penyerapan panas oleh sistem sebaliknya akan menjadi lebih tinggi.
\end{abstract}

Kata Kunci: Penukar Panas; Baffle; Temperatur; Inlet; Outlet.

\begin{abstract}
ABSTRACK
Heat exchangers or heat exchangers are tools used to change the temperature of the fluid or change the fluid phase by exchanging heat with another fluid. In a heat exchanger, the ability to exchange heat is largely determined by the type of fluid flow and fluid passing through the heat exchanger. The use of heat exchangers in the field of drying is now a necessity to overcome the problems of drying productivity. The purpose of this study was carried out to determine the effectiveness of the heat exchanger experimentally based on directional flow by comparing construction using baffle and without using baffle in an effort to optimize the drying system. The research method was carried out by fabricating 2 units of heat exchangers and by field testing. The test data obtained are the input and output temperatures of the heating fluid flow and cooling fluid flow and flow velocity. Based on preliminary research data shows that the use of baffle affects the increase in temperature on the heat exchanger, where at the fresh air outlet that does not use baffle produces a temperature of $72^{\circ} \mathrm{C}$ while the baffle produces $88^{\circ} \mathrm{C}$ with the Log Mean Temperature Difference heat exchanger without using a baffle higher than heat exchanger that uses a baffle guide blade. This can illustrate that the smaller heat losses are wasted so that the absorption of heat by the reverse system will be higher.
\end{abstract}

Keywords: Heat Exchanger; Baffle; Temperature; Inlet; Outlet. 


\section{PENDAHULUAN}

Alat penukar panas (heat exchanger) adalah suatu alat yang digunakan untuk mengubah temperatur fluida atau mengubah fasa fluida dengan cara mempertukarkan panasnya dengan fluida lain. Kemampuan mempertukarkan panas sangat ditentukan oleh jenis aliran fluida dan fluida yang melewati penukar panas. Alat penukar panas dirancang sebisa mungkin agar perpindahan panas antar fluida dapat berlangsung secara efisien. Pertukaran panas terjadi karena adanya kontak, baik antara fluida terdapat dinding yang memisahkannya maupun keduanya bercampur langsung begitu saja.

Berdasarkan arah aliran fluida, penukar panas dibedakan menjadi 3 (tiga) jenis aliran, yaitu aliran searah (parallel flow), aliran berlawanan (counter flow) dan aliran silang. Pada penukar panas jenis aliran searah, fluida yang memanaskan dan fluida yang dipanaskan masuk pada sisi yang sama kemudian keluar pada sisi yang sama pula. Pada penukar panas aliran berlawanan, kedua fluida masuk dan keluar pada sisi yang berbeda, sedangkan pada penukar panas aliran silang, kedua fluida mengalir dengan saling bersilangan.

Saat ini penukar panas banyak dipakai dalam industri pengolahan minyak dan gas Selain itu penukar panas juga banyak dipakai dalam aplikasi industri pengeringan produk-produk pertanian, perkebunan dan perikanan skala besar. Sedangkan dalam industri kecil dan menengah umumnya masih mengandalkan pengeringan dengan pengeringan matahari yang membutuhkan lahan yang besar dan waktu pengeringan yang lama sebagaimana ditunjukkan gambar di bawah ini:
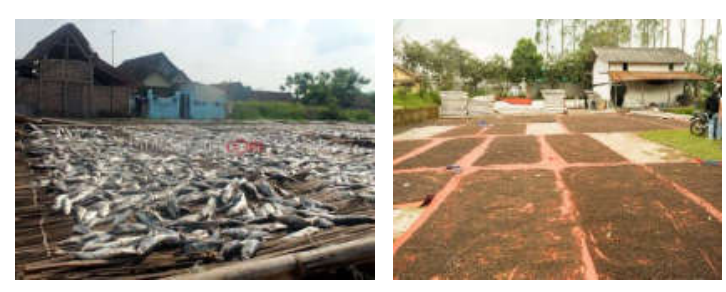

Gambar 1. Pengeringan yang mengandalkan sinar matahari langsung
Penggunaan penukar panas dalam bidang pengeringan saat ini sudah menjadi kebutuhan untuk mengatasi permasalahan pengeringan langsung yang membutuhkan waktu yang relatif lama dan area pengering yang luas. Dan beberapa penelitian telah dilakukan untuk mengetahui efektifitas penukar panas tersebut. Sebagai contoh penelitian yang dilakukan oleh Angga Riansyah[1] melakukan penelitian pengeringan ikan menggunakan alat penukar panas dalam bentuk oven. Hasil penelitian menunjukkan perbedaan suhu pengovenan berpengaruh terhadap kadar air ikan yang dikeringkan. Temperatur pengeringan terbaik diperoleh pada $70^{\circ} \mathrm{C}$ dengan waktu pengeringan 12 jam dan kadar air 39,05\%. Selanjutnya Rezky Fadil Arnaw,dkk[2] juga melakukan penelitian tentang studi numeric pengaruh baffle Inclination pada alat penukar kalor tipe shell and tube terhadap aliran fluida dan perpindahan panas. Hasil penelitian menunjukkan bahwa pada alat penukar panas aliran searah (parallel flow) dengan baffle inclination $0^{0}$ memiliki nilai perpindahan panas terbaik jika dibandingkan dengan baffle inclination $10^{\circ}$ dan $20^{\circ}$. Syukran[3] juga melakukan penelitian tentang Kaji Efisiensi Temperatur Penukar Panas Dengan Variasi Aliran Untuk Aplikasi Pengering. Hasil penelitian menunjukkan bahwa Dari ketiga jenis penukar panas, maka penukar panas alliran silang cenderung memiliki nilai outlet temperaur tertinggi, yakni $52,2^{\circ} \mathrm{C}$. Sedangkan penukar panas aliran searah dan aliran berlawanan memiliki outlet temperatur masing-masing $47,6^{\circ} \mathrm{C}$ dan $48,4^{\circ} \mathrm{C}$.

Berdasarkan hal tersebut maka perlu dilakukan penelitian perbandingan heat exchanger aliran searah menggunakan baffle dan tanpa menggunakan baffle, tujuannya untuk mengetahui efektifitas penukar panas secara eksperimental berdasarkan aliran searah dalam upaya optimasi sistem pengering. Hasil penelitian ini nantinya sangat diperlukan dalam mengembangan model/ produk pengering yang terbaik dapat difabrikasi sesuai dengan karakteristik batasan temperatur aman produk pengering yang ditentukan. 


\section{METODE PENELITIAN}

\subsection{Penukar Panas}

Komoditas alat penukar/pemindah panas adalah alat-alat yang digunakan untuk mengubah temperatur fluida atau mengubah fasa fluida dengan cara mempertukarkan panasnya dengan fluida lain. Arti mempertukarkan di sini adalah memberikan atau mengambil panas. Pemahaman teknologi heat exchanger membutuhkan pengetahuan dalam bidang termodinamika, mekanika fluida, heat transfer, ilmu material dan proses produksi.

Penukar panas umumnya merupakan peralatan di mana dua jenis fluida yang berbeda temperaturnya dialirkan ke dalamnya dan saling bertukar panas melalui bidang-bidang perpindahan panas atau dengan cara kontak langsung (bercampur). Bidang-bidang ini umumnya berupa dinding pipa-pipa atau siripsirip yang dipasangkan pada pipa (fin).

Panas yang dipindahkan di antara fluida tersebut, besarnya tergantung pada kecepatan dan arah aliran, sifat-sifat fisika fluida, kondisi permukaan, luas perpindahan panas dan beda temperatur diantara kedua fluida. Fluida yang mengalir di dalam penukar panas kadangkadang mengandung zat-zat yang dapat mengendap /mengerak pada permukaan pipa atau bereaksi dan menyebabkan korosi atau kerusakan lainnya, sehingga kinerja penukar panas dapat menjadi menurun.

\subsection{Jenis-jenis Penukar Panas}

Penukar panas secara garis besar dibagi berdasarkan arah aliran fluidanya. Berdasarkan arah aliran fluida, penukar panas dibedakan menjadi 3 jenis aliran, yaitu: aliran searah (parallel flow), aliran berlawanan (counter flow) dan aliran silang (cross flow). Pada penukar panas jenis aliran searah, fluida yang memanaskan dan fluida yang dipanaskan masuk pada sisi yang sama kemudian keluar pada sisi yang sama. Pada penukar panas aliran berlawanan, kedua fluida masuk dan keluar pada sisi yang berbeda, sedangkan pada penukar panas aliran silang, kedua fluida mengalir dengan saling bersilangan. Ilustrasi ketiga jenis penukar panas tersebut dapat dilihat pada Gambar 2.
Berdasarkan jenis fasa fluida yang mengalir, heat exchanger dapat dibagi menjadi:

- Tipe cair - gas. Contohnya radiator mobil, cooler oli, peralatan pengkondisian udara, dan refrejerasi, intercooler dan after cooler untuk kompresor serta cooler udara pada turbin gas.

- Tipe cair-cair

- Tipe gas-gas (dimensinya lebih besar dibanding yang lain).
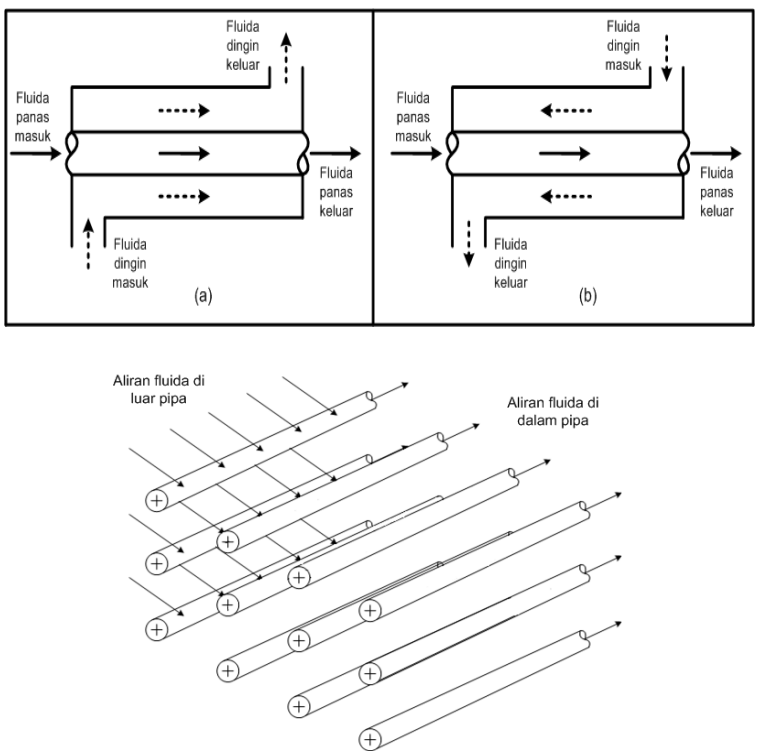

Gambar 2. (a) Penukar panas aliran searah (paralel flow) (b) Penukar panas aliran berlawanan (counter flow)

(c) Penukar panas aliran silang (cross flow)

Luas permukaan perpindahan panas yang dapat menghasilkan perubahan temperatur kedua fluida merupakan perbedaan utama di antara ketiga jenis penukar panas di atas. Gambar berikut ini menunjukkan luas perpindahan panas yang diperlukan masing-masing jenis penukar panas untuk mencapai perubahan temperatur fluida 


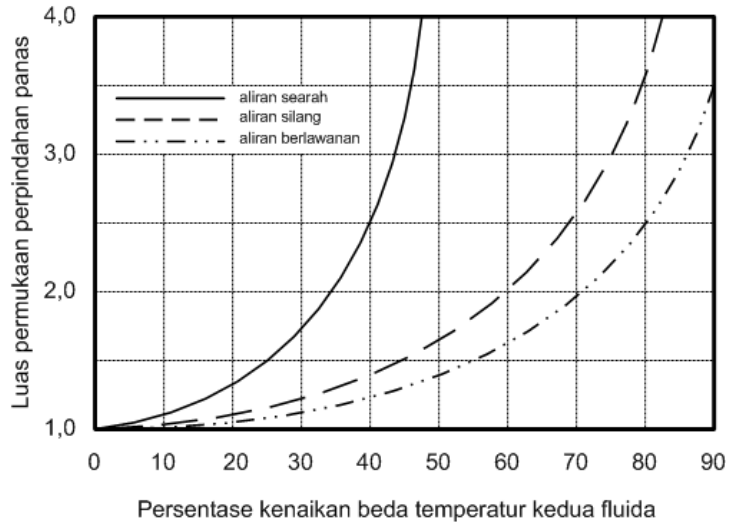

Gambar 3. Hubungan luas permukaan perpindahan panas dengan persentase kenaikan beda temperatur fluida

Berdasarkan gambar tersebut, terlihat bahwa penukar panas aliran searah memerlukan luas permukaan yang lebih besar dari pada kedua jenis yang lain untuk mencapai perubahan temperatur yang sama. Penukar panas aliran berlawanan memiliki luas permukaan perpindahan panas yang paling kecil.

Penukar panas aliran silang biasanya dipasang sirip-sirip (fins) untuk meningkatkan luas permukaan perpindahan panas. Penukar panas ini disebut penukar panas kompak (compact heat exchanger). Arti penukar panas kompak adalah penukar panas yang memiliki perbandingan luas permukaan perpindahan panas terhadap volume penukar panas yang lebih besar atau sama dengan 700. Sirip-sirip yang dipasang memiliki kerapatan yang tinggi, antara 5-20 sirip per inchi. Sekurang-kurangnya salah satu fluida yang digunakan pada penukar panas kompak adalah berfasa gas. Jenis penukar panas yang dibahas pada penelitian ini adalah penukar panas kompak dengan geometri pipa berbentuk bulat (circular tubes).

\subsection{Mekanisme Perpindahan Panas Penukar Panas}

Perpindahan panas terjadi jika terdapat perbedaan temperatur antara dua buah zat, baik padat, cair, maupun gas. Energi dalam bentuk panas berpindah dengan 3 (tiga) macam mekanisme, yaitu secara konduksi, konveksi, dan radiasi. Perpindahan panas secara konduksi dan radiasi hanya bergantung dari perbedaan temperatur, sedangkan pada konveksi selain bergantung pada temperatur juga bergantung pada perpindahan massa yang terjadi.
Untuk menganalisis perpindahan panas pada penukar panas dalam penelitian ini, mekanisme perpindahan panas yang diperhatikan adalah konduksi dan konveksi, sedangkan mekanisme secara radiasi tidak dominan sehingga dapat diabaikan. Namun pada beberapa kasus, laju perpindahan panas konduksi juga dapat diabaikan, karena sangat kecil dibandingkan konveksi. Secara keseluruhan, mekanisme perpindahan panas yang terjadi di dalam sebuah penukar panas kompak adalah:

- konduksi melalui dinding pipa

- konveksi paksa di dalam pipa

- konveksi paksa di luar pipa

\subsection{Prinsip Perhitungan Perpindahan Panas pada Penukar Panas}

Dalam perhitungan kinerja penukar panas, dikenal istilah TTD dan TD. TTD atau terminal temperature difference adalah beda temperatur terbesar pada salah satu sisi ujung. Sedangkan TD atau temperatur difference beda temperatur terkecil pada ujung lainnya.

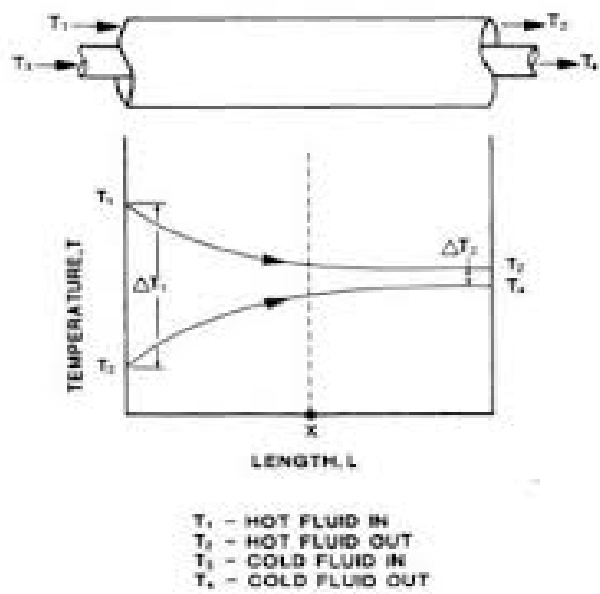

Gambar 4. Skematik TD dan TTD pada penukar panas

Persamaan energi:

$$
\begin{array}{r}
\text { m1.c1. }(T p 1-T p 2) \\
=m 2 . c 2 .(T d 2-T d 1)
\end{array}
$$

Perpindahan panas konveksi :

$$
\begin{gathered}
Q=U \cdot A \cdot(L M T D) \\
L M T D=\frac{\Delta T_{A}-\Delta T_{B}}{\log \left(\frac{\Delta T_{A}}{\Delta T_{B}}\right)} \\
L M T D=\frac{\Delta T_{A}-\Delta T_{B}}{\ln \left(\frac{\Delta T_{A}}{\Delta T_{B}}\right)}=\frac{\left(T_{h, i}-T_{C, 0}\right)-\left(T_{h, o}-T_{C, i}\right)}{\ln \left[\left(T_{h, i}-T_{C, 0}\right) /\left(T_{h, O}-T_{C, i}\right)\right]}
\end{gathered}
$$


Dimana:

$\Delta \mathrm{T}_{\mathrm{A}}=$ beda tempearatur kedua fluida pada satu sisi penukar panas (maksimum)

$\Delta \mathrm{T}_{\mathrm{B}}=$ Beda temperatur kedua fluida pada sisi lainnya dari penukar panar (minimum).

Log mean temperature difference (juga dikenal dengan LMTD) digunakan untuk menentukan kekuatan pendorong suhu untuk perpindahan panas dalam sistem aliran, terutama dalam penukar panas. LMTD adalah rata-rata logaritmik dari perbedaan suhu antara aliran panas dan dingin di setiap akhir exchanger. Semakin besar LMTD, semakin banyak panas yang ditransfer. Penggunaan LMTD muncul lugas dari analisis penukar panas dengan laju alir konstan dan sifat termal fluida.

\subsection{Tinjauan Udara Pengering Produk Pertanian dan Perkebunan}

Bahan baku produk hasil pertanian memerlukan kualitas yang baik. Salah satu parameter yang menunjukkan kualitas bahan baku yang baik adalah kadar air yang terkandung dalam bahan baku. Kandungan air bahan baku dinyatakan dalam persentase massa. Pada umumnya bahan baku yang akan diumpankan ke ruang pengering disyaratkan memiliki kandungan air tertentu. Bahan baku yang berasal dari tempat penyimpanan memiliki kandungan air yang masih tinggi. Tabel 1 menunjukkan data kandungan air rata-rata beberapa jenis produk pertanian.

Tabel 1. Kandungan kadar air beberapa produk pertanian dan perkebunan[5]

\begin{tabular}{|c|c|c|c|c|c|}
\hline No & $\begin{array}{l}\text { Nama } \\
\text { Produk }\end{array}$ & $\begin{array}{c}\text { Kadar } \\
\text { air } \\
\text { sesudah } \\
\text { panen }\end{array}$ & $\begin{array}{c}\text { Kadar } \\
\text { air } \\
\text { Normal }\end{array}$ & $\begin{array}{l}\text { Kadar air } \\
\text { Yang } \\
\text { diharapkan }\end{array}$ & $\begin{array}{c}\text { Temperatur } \\
\text { diizinkan }\end{array}$ \\
\hline 1. & Kakau & $\begin{array}{c}65- \\
70 \%\end{array}$ & $22 \%$ & $6-7 \%$ & $\begin{array}{c}60-70 \\
{ }^{0} \mathrm{C}\end{array}$ \\
\hline 2. & Kopi & $58 \%$ & $44 \%$ & $11 \%$ & $\begin{array}{c}45-58 \\
{ }^{0} \mathrm{C}\end{array}$ \\
\hline 3. & Pinang & $60 \%$ & $20 \%$ & $12 \%$ & $\begin{array}{l}50- \\
60^{0} \mathrm{C}\end{array}$ \\
\hline 4. & Kedelai & $48 \%$ & $15 \%$ & $5-7 \%$ & $\begin{array}{c}40-50 \\
{ }^{0} \mathrm{C}\end{array}$ \\
\hline
\end{tabular}

Dalam pengeringan bahan baku, terdapat batasan-batasan temperatur yang perlu diperhatikan. Temperatur maksimum gas pengering tidak boleh terlalu tinggi. Selain itu, proses pemanasan yang terjadi tidak boleh menyebabkan perubahan struktur kimia bahan baku. Temperatur gas pengering yang keluar dari ruang pengering dijaga agar tidak terlalu rendah, supaya tidak terjadi kondensasi uap air yang ada dalam gas.

Dalam memperhitungkan kebutuhan energi panas untuk pengeringan bahan baku, ada beberapa komponen penting energi panas yang perlu diperhitungkan. Menurut literatur, untuk mengeringkan suatu material dengan kandungan air awal 40\% 70\%. Persentase komponen energi panas untuk pengeringan material tersebut adalah:

- Energi panas untuk menguapkan air : $50 \%$

- Energi panas untuk memanaskan air : 5\%

- Energi panas untuk memanaskan material : $15 \%$

- Energi panas yang terbawa gas keluar pengering : $12 \%$

- Energi panas terbuang ke lingkungan : $18 \%$

Total energi panas yang diberikan gas pengering : $100 \%$

Untuk mempermudah perhitungan, tidak semua komponen energi panas diperhitungkan. Komponen energi panas yang dihitung adalah komponen nomor a, b, dan c saja. Maka energi panas yang digunakan untuk pengeringan bahan baku hanya $70 \%$ total energi panas yang tersedia dari gas pengering. Dengan kata lain efisiensi pengeringan bahan baku adalah $70 \%$. Kisaran efisiensi pengeringan suatu material menurut literatur adalah antara $70-75 \%$.

\subsection{Metode dan Alat}

Peralatan uji penelitian ini terdiri dari 2 unit alat penukar panas yaitu penukar panas aliran searah tanpa baffle dan menggunakan baffle. Kedua jenis penukar panas tersebut memiliki spesifikasi sebagai berikut:

$\begin{array}{ll}\text { Tipe } & : \text { Rectangular Shell / Circular } \\ & \text { Tube } \\ \text { Jenis aliran } & : \text { Paralel flow } \\ \text { Dimensi } & : \text { Rectangular Shell } 50 \text { (P) x } 30 \\ & \text { (L) x 10 (T) (ASTM SA.36) } \\ \text { Tube } & : 0.5 \text { inchi (ASTM SA.53) } \\ \text { Header Inlet } & : 4 \text { inchi }\end{array}$


Header Outlet : 4 inchi

Kedua Rancangan alat uji penukar panas tersebut seperti ditunjukkan Gambar 5 berikut:

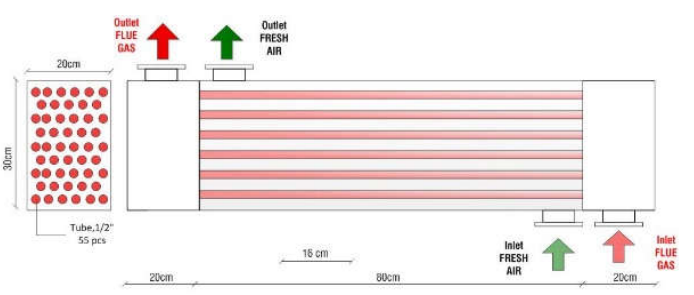

(a)

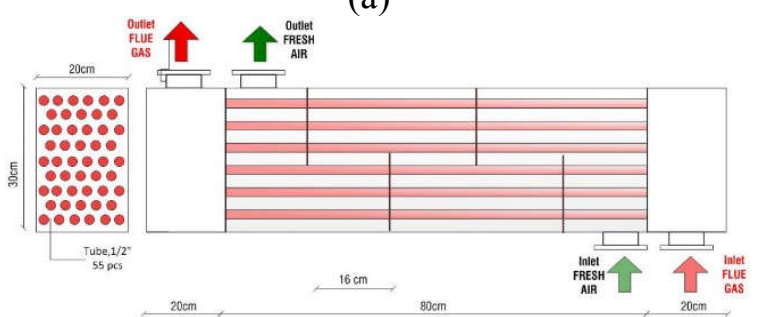

(b)

Gambar 5. Rancangan alat uji penukar panas (a) tanpa menggunakan baffle dan

(b) menggunakan baffle

Parameter pengujian yang menjadi fokus penelitian ini adalah temperatur inlet fluida dingin, temperatur outlet fluida dingin temperatur inlet fluida panas, temperatur outlet panas, kecepatan alir fluida. Pengukuran temperatur dilakukan menggunakan termocouple dan pengukuran aliran dilakukan menggunakan anemometer udaraseperti ditunjukkan Gambar 6 berikut:

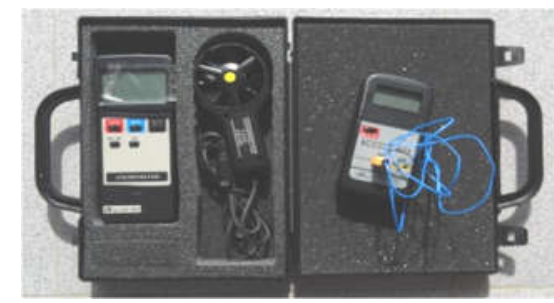

Gambar 6. Alat ukur termocouple dan anemometer

Data pengujian yang diukur dalam penelitian ini terdiri dari :

- Temperatur aliran flue gas inlet $\left({ }^{\circ} \mathrm{C}\right)$

- Temperatur aliran flue gas outlet $\left({ }^{\circ} \mathrm{C}\right)$

- Temperatur aliran fresh air inlet $\left({ }^{\circ} \mathrm{C}\right)$

- Temperatur aliran fresh air outlet $\left({ }^{\circ} \mathrm{C}\right)$

- Kecepatan aliran flue gas inlet $(\mathrm{m} / \mathrm{s})$

- Kecepatan aliran flue gas outlet $(\mathrm{m} / \mathrm{s})$

- Kecepatan aliran fresh air inlet $(\mathrm{m} / \mathrm{s})$

- Kecepatan aliran fresh air outlet $(\mathrm{m} / \mathrm{s})$

\section{HASIL DAN PEMBAHASAN}

Berdasarkan data hasil pengujian maka dapat digambarkan Grafik perbandingan temperatur fresh air inlet dan outlet antara penukar panas menggunakan baffle dan tanpa baffle.

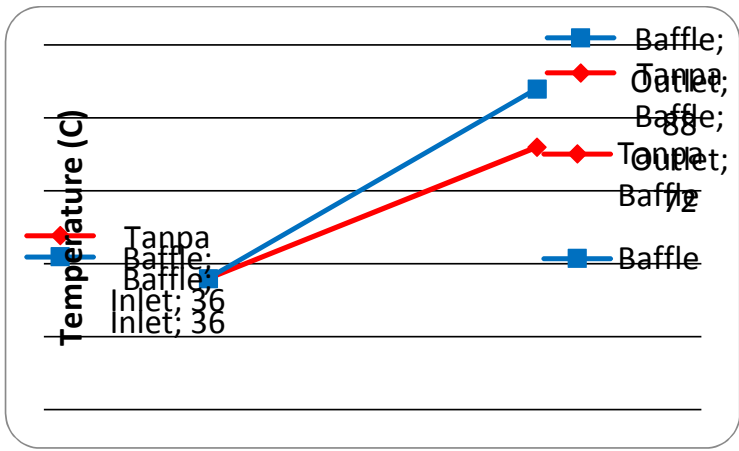

Gambar 7. Gradien temperatur aliran searah

Berdasarkan data awal hasil penelitian sesuai dengan grafik diatas maka dapat dijelaskan bahwa kinerja heat exchanger tanpa menggunakan baffle dan menggunakan baffle akan meningkatkan perpindahan panas yang terjadi di antara kedua fuida terutama pada fluida fresh air, hambatan yang terjadi pada aliran yang melalui celah antar baffle menjadi besar sehingga penurunan tekanan menjadi besar, pada aliran outlet fresh air yang tidak menggunakan baffle menghasilkan temperature sebesar $72^{\circ} \mathrm{C}$ dengan kecepatan fluida $4,05 \mathrm{~m} / \mathrm{s}$ sedangkan yang menggunakan baffle menghasilkan temperature sebesar $88^{\circ} \mathrm{C}$ dengan kecepatan 3,66 m/s.

Dari data tersebut terlihat bahwa terjadi peningkatan temperatur yang signifikan pada alat penukar panas yang menggunakan baffle, ini terjadi karena perlambatan aliran panas menuju outlet flue gas yang dikarenakan oleh hambatan baffle dan juga ini mempengaruhi perlambatan kecepatan fluida pada alat penukar panas menggunakan baffle dari $4,05 \mathrm{~m} / \mathrm{s}$ menjadi $3,66 \mathrm{~m} / \mathrm{s}$.

Berdasarkan data tersebut, maka kedua alat penukar panas tersebut berpeluang sebagai media penghasil udara pemanas untuk aplikasi pengering produk pertanian sesuai dengan tabel 1.

Kemudian berdasarkan data tersebut maka dapat ditentukan nilai dari Log Mean Temperature Difference (LMTD) dari kedua penukar panas seperti berikut: 


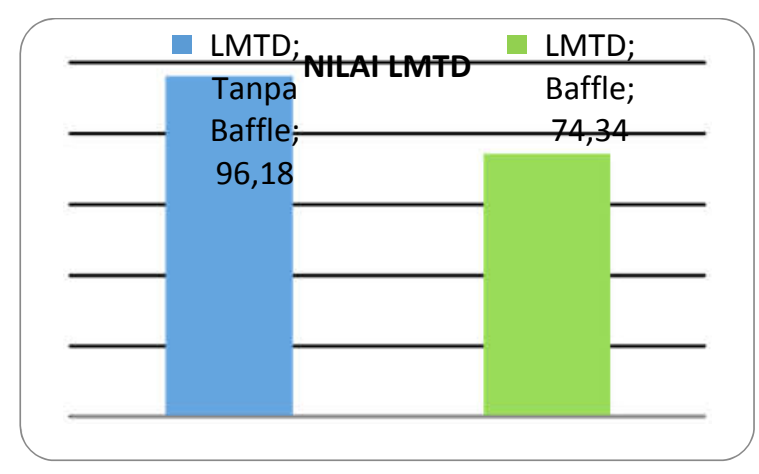

Gambar 8. Nilai LMTD

Berdasarkan Gambar 8 dapat dijelaskan bahwa nilai Log Mean Temperature Difference (LMTD) untuk alat penukar panas yang menggunakan baffle lebih kecil dibandingkan dengan tanpa menggunakan baffle. Nilai LMTD penukar panas tanpa baffle adalah sebesar $96,18^{\circ} \mathrm{C}$ lebih tinggi dibanding dengan LMTD penukar panas menggunakan baffle yang hanya sebesar $74,34^{\circ} \mathrm{C}$. Rendahnya nilai LMTD tersebut disebabkan oleh efek pemasangan baffle yang menunjukkan bahwa selisih temperatur rata-rata logaritmik antara fluida pemanas dengan fluida yang dipanaskan semakin kecil pada sisi inlet dan outlet. Hal ini memberi informasi bahwa pelepasan panas (heat losses) semakin kecil yang terbuang sehingga penyerapan panas oleh sistem sebaliknya menjadi tinggi.

\section{KESIMPULAN}

Berdasarkan hasil penelitian maka dapat disimpulkan bahwa:

- Kinerja heat exchanger tanpa menggunakan baffle dan menggunakan baffle sangat mempengaruhi nilai peningkatan perpindahan panas atau temperature yang terjadi di antara kedua fuida.

- Dari kedua jenis alat penukar panas yang telah difabrikasi, maka alat penukar panas alliran searah menggunakan baffle memiliki nilai outlet temperatur paling tinggi sebesar $88^{\circ} \mathrm{C}$ dibandingkan dengan alat penukar panas tanpa menggunakan baffle yang temperaturnya hanya $72{ }^{\circ} \mathrm{C}$.

- Nilai Log Mean Temperature Difference penukar panas tanpa menggunakan baffle lebih tinggi daripada penukar panas yang menggunakan sudu pengarah baffle. Hal ini bisa menggambarkan bahwa pelepasan panas (heat losses) semakin kecil yang terbuang sehingga penyerapan panas oleh sistem sebaliknya akan menjadi lebih tinggi

\section{DAFTAR PUSTAKA}

[1] Angga Riansyah, dkk. (2013,Nov.) "Pengaruh perbedaan suhu dan waktu pengeringan terhadap karakteristik ikan asin sepat siam", Jurnal Fishtech, 2(1)

[2] Rezky Fadil Arnaw,dkk (2014) studi numerik pengaruh baffle Inclination pada alat penukar kalor tipe shell and tube terhadap aliran fluida dan perpindahan panas, Jurnal Teknik Pomits, ITS, Vol.3, No.2, 2014

[3] Syukran (2018, Aug.) "Kaji Efisiensi Temperatur Penukar Panas Dengan Variasi Aliran Untuk Aplikasi Pengering". Jurnal Polimesin, 16(2), pp.39-42.

[4] Arthur P. Fraas, Heat Exchanger Design, John Wiley \& Sons, United States of America, 1988

[5] Ditjenbun. 2006. Statistik Perkebunan Indonesia. Direktorat Jendral Perkebunan, Departemen Pertanian, Jakarta.

[6] Ai Rukmini, Perancangan uji penukar panas (Heat Exchanger) tipe counter flow, Fakultas Teknologi Pertanian, Institut Teknologi Pertanian, IPB Bogor, 2006

[7] M. Yahya. (2013, Oct.) "Alat Pengering hasilhasil pertanian untuk daerah pedesaan di Sumatera Barat". Jurnal Teknik Mesin Institut Teknologi Padang, 3(2), pp.26-31

[8] C.M. Vant Land, Industrial Drying EquipmentSelection and Application, Marcel Dekker, Inc, America, 1991

[9] Incropera, F.P \& Dewitt D.P, 1996, Introduction to Heat Transfer", $3^{\text {rd }}$ Edition, John Wiley \& Sons, Canada.

[10] I Made Agus Wirawan, dkk, 2016, analisa pengaruh variasi laju aliran udara terhadap efektifitas heat exchanger memanfaatkan energy panas LPG, Jurnal Ilmiah Teknik Desain Mekanika Univ. Udayana Bali, Vol. No. (xx), Juli 2016. 